\title{
PENGARUH KEPEMIMPINAN DAN KINERJA DOSEN TERHADAPMUTU PELAYANAN DI POLITEKNIK NEGERI BATAM
}

\author{
Shinta Wahyu Hati \\ Program Studi Administrasi Bisnis Terapan Politeknik Negeri Batam \\ shinta@polibatam.ac.id
}

\begin{abstract}
In general education at the college level to prioritize quality of service as the primary goal, because the quality of service quality is a major factor to demonstrate the performance of the organization will be the desire and commitment of stakeholders. This study aims to analyze the influence of leadership on employee performance and its effect on the quality of service. Object of this study is its staff Polytechnic Batam, Riau Island. The samples were 50 employees lecturer. Data were collected using a questionnaire. The findings of this study indicate that the value of $\mathrm{R}$ square is 0.681 . Shows the value of effective leadership and faculty performance is quite good, will raise the quality of service at the Polytechnic of $68.1 \%$. Subsequent research findings employee performance variables lecturer dominant influence on the quality of service quality in Batam Polytechnic of $55.9 \%$
\end{abstract}

Keywords: leadership, performance, quality service

Dalam perusahaan jasa khususnya pada layanan jasa pendidikan, kinerja individu maupun kelompok sangat mempengaruhi kinerja organisasi, hal ini disebabkan oleh adanya proses pekerjaan yang membutuhkan "ketepatan waktu dan aman (safe)" bagi mahasiswa sebagai konsumen, sehingga jasa yang diberikan bisa diterima dengan baik. Ruang lingkup pelayanan dalam bidang penyelenggaraan pendidikan sangat besar khususnya pelayanan pada mahasiswa dalam pelaksanaan PBM dan pembinaan pada mahasiswa. Kewajiban untuk memberi mutu pelayanan yang baik dan prima pada mahasiswa adalah kewajiban para tenaga pendidik dan tenaga kependidikan. Bentuk dan proses pelayanan yang diberikan merupakan kinerja dalam bidang jasa pendidikan. Banyak hal yang dapat mempengaruhi kinerja, sehingga pihak manajemen harus menjaga faktor-faktor yang dapat berpengaruh terhadap kinerja, agar dapat terpenuhi secara maksimal. Peningkatan kinerja karyawan di institusi pendidikan secara perorangan akan mendorong kinerja sumber daya manusia secara keseluruhan, yang direkflesikan dalam kenaikan produktifitas.

Berdasarkan uraian di atas menunjukkan penilaian kinerja merupakan suatu hal yang tidak dapat dipisahkan dengan organisasi khususnya di Institusi pendidikan yang berbasis vokasi. Penilaian kinerja dengan berbagai bentuk seperti key performance indicator atau key performance Index pada dasarnya merupakan suatu sasaran dan proses sistimatis untuk mengumpulkan, menganalisa dan menggunakan informasi untuk menentukan efisiensi dan efektivitas tugas-tugas karyawan serta pencapaian sasaran. Menurut Amstrong (1998), penilaian kinerja didasarkan pada pengertian knowledge (pengetahuan), Skill (ketrampilan), expertise (keahlian) dan behavior (perilaku) yang diperlukan untuk mengerjakan pekerjaan dengan baik dan analisis lebih luas terhadap attributes (sifat) dan perilaku individu.

Kinerja merupakan suatu fungsi dari motivasi dan kemampuan. Untuk menyelesaikan tugas atau pekerjaan, seseorang harus memiliki derajat kesediaan dan tingkat kemampuan tertentu. Kesediaan dan ketrampilan seseorang tidaklah cukup efektif untuk mengerjakan sesuatu tanpa pemahaman yang jelas tentang apa yang akan dikerjakan dan bagaimana mengerjakannya (Harsey and Blanchard, 1993). Sumber daya manusia yang berbakat, berkualitas, bermotivasi tinggi dan mau bekerja sama dalam team akan menjadi kunci keberhasilan organisasi. Karena itu pimpinan harus dapat menetapkan sasaran kerja yang akan menghasilkan karyawan yang berkualitas tinggi, bermotivasi tinggi dan produktif. Penetapan target-target spesifik dalam kurun waktu tertentu tidak hanya bersifat kuantitatif tetapi juga bersifat kualitatif misalnya, dengan pengembangan diri untuk menguasai pengetahuan dan keahlian yang diperlukan untuk pekerjaan dengan tingkat kompetensi yang makin baik. 
Penilaian kinerja tenaga pendidik dan kependidikan sebagai pelaku di institusi pendidikan Politeknik, dengan membuat ukuran kinerja yang sesuai dengan tujuan organisasi. Standar penilaian kinerja suatu organisasi harus dapat diproyeksikan ke dalam standar kinerja para karyawan sesuai dengan unit kerjanya. Evaluasi kinerja harus dilakukan secara terus menerus agar tujuan organisasi dapat tercapai secara efektif dan efisien. Pihak manajemen Politeknik perlu mengetahui berbagai kelemahan atau kelebihan staf pendidik dan kependidikan sebagai landasan untuk memperbaiki kelemahan dan menguatkan kelebihan dalam rangka meningkatkan kinerja karyawan.

Era globalisasi dan memasuki Asean Economic Community 2015 yang disertai dengan meningkatnya jenjang pendidikan dan pengetahuan masyarakat pada akhirnya menuntut semua institusi khususnya yang bergerak dibidang pelayanan jasa untuk meningkatkan mutu dan pelayanan yang profesional, tidak terkecuali pelayanan dalam bidang pendidikan vokasi. Perkembangan ilmu pengetahuan dan teknologi serta globalisasi merupakan suatu yang sudah menjadi kebutuhan masyarakat, terutama terhadap kualitas pelayanan pendidik membawa konsekuensi pada tuntutan terhadap profesionalisme. Pelayanan pendidikan yang bermutu dan profesional dapat diberikan apabila didukung oleh sumber daya tenaga pendidik yaitu tenaga pendidik atau dosen.

Kinerja organisasi merupakan instraksi yang kompleks dan agregasi kinerja sejumlah individu dalam organisasi. Pengaruh pimpinan dalam organisasi yang kondusif akan mampu menggerakkan fungsi karyawan dalam melaksanakan tugasnya. Pengelolaan pendidikan vokasi seperti Politeknik yang berdasarkan aturan dalam undang-undang pendidikan perlu mendapat perhatian yang serius karena mutu pelayanan yang disampaikan di Politeknik adalah berbasis terapan yang tentunya memiliki kareteristik yang berbeda dengan pendidikan di universitas atau Sekolah Tinggi. Pengelolaan pelayanan yang bermutu di Politeknik Negeri Batam berpedoman pada ISO: 2008 dimana dalam pengelolaan yang dijalankan disesuaikan dengan prosedur mutu, ketaatan staf pendidik khususnya dosen dalam menjalankan tugas dan kewajibannya sesuai dengan indikator dalam proses bisnis di Politeknik Negeri Batam.

Memasuki Asean Economic Community tahun 2015 Politeknik Negeri Batam harus sebagai institusi yang berperan dalam membangun SDM melalui pendidikan di daerah perbatasan negera dengan Singapura harus memperhatikan dan berinovasi dalam mutu pelayanan. Mutu pelayanan ini adalah kebutuhan dan tanggung jawab yang harus selalu ditingkatkan ke arah yang lebih baik. Sebagai institusi pendidikan yang ada di perbatasan Negara yaitu Singapura, Pengelolaan manajemen dalam hal ini adalah kepemimpinan serta dosen di Politeknik Negeri Batam harus selalu berbenah dan berinovasi dalam memperbaiki mutu pelayanan.

Tujuan penellitian ini adalah untuk mengetahui dan menganalisis: (1) Pengaruh kepemimpinan terhadap mutu pelayanan di Politeknik Negeri Batam. (2) Pengaruh kinerja dosen terhadap mutu pelayanan di Politeknik Negeri Batam. (3) Pengaruh kepemimpinan dan kinerja dosen terhadap mutu pelayanan di Politeknik Negeri Batam.

\section{Kerangka Konsep Penelitian}

Menurut Sekaran (2006) kerangka konseptual merupakan model konseptual mengenai bagaimana teori berhubungan dengan berbagai faktor atau variabel, yang telah dikenali atau diidentifikasi sebagai masalah yang penting sekali. Suatu kerangka konseptual akan memberikan penjelasan sementara, terhadap gejala yang menjadi masalah (objek) penelitian. Sehubungan dengan hal tersebut maka diskripsi teori dan penelitian terdahulu merupakan landasan utama untuk menyusun kerangka konseptual yang pada akhirnya digunakan dalam merumuskan hipotesis.

Teori-teori pendukung dalam penelitian ini adalah sebagai berikut: Teori kepemimpinan oleh Gary, Yuki (1994), Thoha (2001), Hershey dan Blanchard (1995), dan definisi Kinerja Pegawai Amstrong (1994), Handoko (1998), As'ad (1999), Simanjuntak (1985), Siagian (1995), Swasto (1996), sementara mutu pelayanan oleh Zeithaml, Valarie, et al. (1996) dan Parasuraman, Zeithaml, et al. (1998)

Sedangkan kerangka konseptual penelitian dapat digambarkan seperti terlihat pada gambar 1 :

\section{Hipotesis Penelitian}

Hipotesis penelitian disusun sebagai berikut: (a) Hipotesis 1, Kepemimpinan berpengaruh signifikan terhadap mutu pelayanan di Politeknik Negeri Batam. (b) Hipotesis 2, Kinerja dosen berpengaruh signifikan terhadap mutu pelayanan di Politeknik Negeri Batam. (c) Hipotesis 3, Kepemimpinan dan kinerja dosen secara bersama-sama berpengaruh signifikan terhadap mutu pelayanan di Politeknik Negeri Batam.

Kepemimpinan (leadership styles) merupakan cara pimpinan (manajer) untuk mempengaruhi orang 


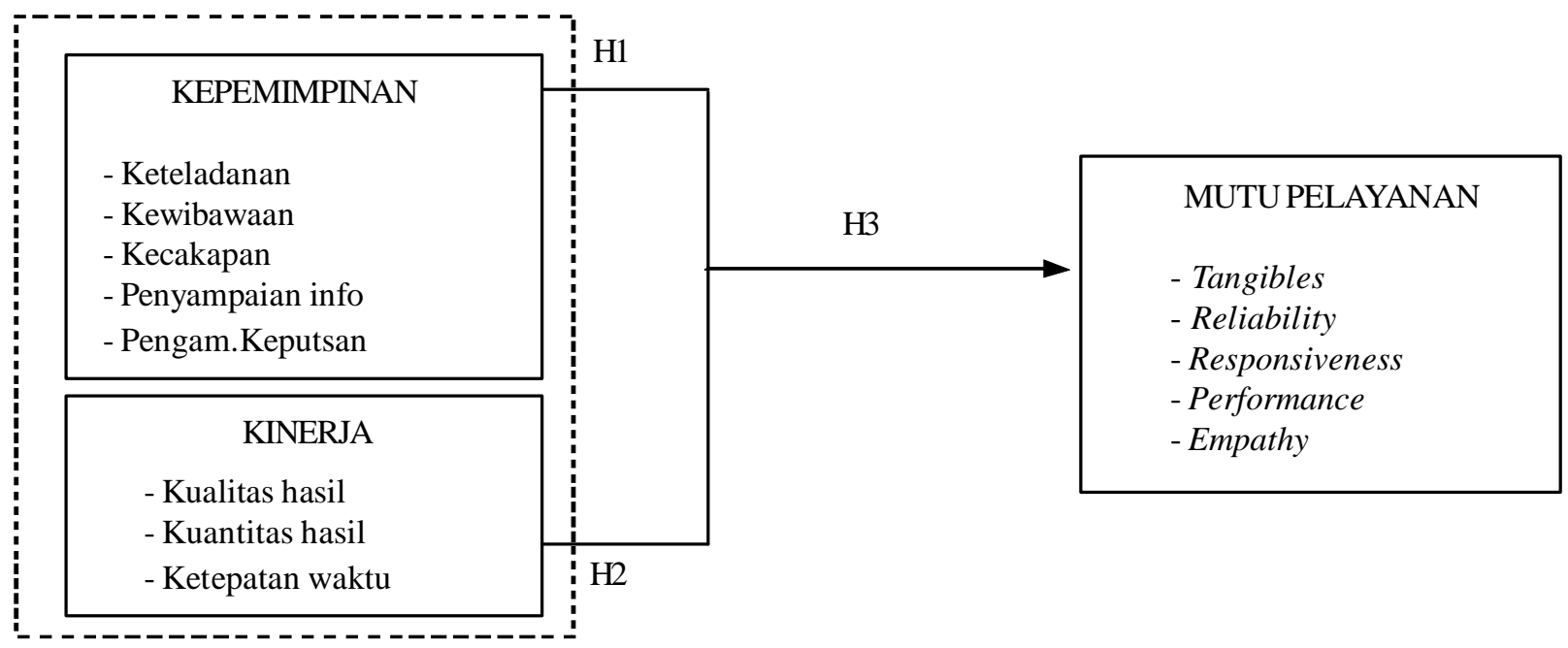

Gambar 1. Kerangka Konsep Penelitian

lain atau bawahannya sedemikian rupa sehingga orang tersebut mau melakukan kehendak pemimpin untuk mencapai tujuan organisasi meskipun secara pribadi hal tersebut mungkin tidak disenangi (Siagian, 2002). Sementra itu Hershey dan Blanchard (1995) menjelaskan tentang model kepemimpinan situasional dan menyimpulkan bahwa gaya kepemimpinan yang paling efektif sangat ditentukan oleh kesiapan pegawai (keinginan untuk berprestasi, kemauan untuk menerima tanggung jawab dan kemampuan melaksanakan tugas serta pengalaman kerjanya).

Kinerja sebagai hasil usaha seseorang yang dicapai dengan kemampuan dan perbuatan dalam situasi tertentu. Penilaian kinerja (performance appraisal) adalah proses melalui mana organisasi-organisasi mengevaluasi atau menilai prestasi karyawan (Handoko, 1998). Sedang Mangkunegara (2000) menyatakan kinerja adalah hasil kerja secara kualitas dan kuantitas yang dicapai oleh karyawan dalam melaksanakan tugasnya sesuai dengan tanggung jawab yang diberikan kepadanya. Hasibuan (1997) mengatakan kinerja adalah suatu hasil kerja yang dicapai seseorang dalam melaksanakan tugas-tugas yang dibebankan kepadanya yang didasarkan atas kecakapan, pengalaman, kesungguhan serta waktu. Sedangkan menurut As'ad (1999) kinerja sebagai hasil yang dicapai oleh seseorang menurut ukuran yang berlaku untuk pekerjaan yang bersangkutan.

Parasuraman, Zeithaml, et al. (1998) mengidentifikasikan lima dimensi kualitas pelayanan (servqual) sebagai berikut: (1) Tangibles, yaitu penampilan fasilitas fisik, termasuk peralatan, personal dan sarana komunikasi. Tangibel dapat mencakup fasilitas atau elemen-elemen fisikal, peralatan personel, dan materi- materi komunikasi. (2) Reliability, yaitu kemampuan perusahaan dalam menepati dan memenuhi janji-janji yang diberikan kepada konsumen secara meyakinkan. Menurut Yasid (1999) adalah kemampuan yang dapat diandalkan, akurat dan konsisten dalam memberikan pelayanan sesuai yang diinginkan konsumen. (3) Responsiveness, cepat tanggap dalam membaca dan melayani kebutuhan konsumen. (4) Assurance, yaitu pengetahuan, kehandalan dan sopan santun pagawai serta dapat dipercaya dan percaya diri. (5) Emphaty, yaitu memberikan perhatian yang tulus dan bersifat individual atau pribadi yang diberikan kepada para konsumen dengan berupaya memahami keinginan konsumen.

\section{METODE}

Rancangan penelitian ini merupakan tipe penelitian penjelasan (explanatif research) dengan melakukan pengamatan atau non-eksperimen karena menjelaskan hubungan kausal antara variabel-variabel melalui pengujian hipotesis tanpa memberikan perlakuan Singarimbun, (2006) serta dengan sampel yang diambil dari suatu populasi dan menggunakan kuesioner sebagai alat pengumpul data yang pokok dan pada umumnya merupakan unit analisa individu.

\section{Populasi dan Sampel}

Populasi merupakan objek atau subjek yang berada pada suatu wilayah dan memenuhi syarat-syarat tertentu berkaitan dengan masalah penelitian. Ada dua jenis populasi, yaitu: populasi terbatas dan populasi tidak terbatas (Riduwan, 2004). Populasi yang diteliti ini adalah dosen Politeknik Negeri Batam. Sampel 
menurut Arikunto (1998) dalam Riduwan (2004) mengatakan bahwa: Sampel penelitian adalah sebagian dari populasi yang diambil sebagai sumber data dan dapat mewakili seluruh populasi. Pengambilan sampel dengan menggunakan purposive sampling, dalam penelitian ini sampel yang digunakan adalah 50 responden dilingkungan Politeknik Negeri Batam. Responden penelitian ini adalah dosen Politeknik Negeri Batam.

Pengambilan informasi dari para responden sebagai sampel ini dilakukan dengan menyebar kuesioner kepada mereka dengan memberikan beberapa butir pertanyaan dan jawaban untuk dipilih. Kemudian dari hasil tanggapan mereka mengenai kepemimpinan, kinerja dosen dan mutu pelayanan di Politeknik Negeri Batam digunakan sebagai dasar analisis dan estimasi untuk mengetahui kebenaran dari hipotesis yang diajukan.

\section{Desain Operasional Variabel}

Tabel 1. Desain Operasional Variabel digunakan analisis regresi berganda karena analisis ini memungkinkan dapat mengisolasikan hubungan langsung dua variabel dengan membuat yang lain konstan.

Formulasi model dari analisis regresi linier berganda dalam penelitian ini adalah sebagai berikut:

$\mathrm{Y}=\mathrm{a}+\mathrm{b}_{1} \mathrm{X}_{1}+\mathrm{b}_{2} \mathrm{X}_{2}+\mathrm{b}_{3} \mathrm{X}_{3}+\ldots \ldots \ldots+\mathrm{b}_{\mathrm{n}} \mathrm{X}_{\mathrm{n}}+\mathrm{e}$

Keterangan:

$\mathrm{Y}=$ Variabel terikat $($ dependent $)$ pada Mutu Pelayanan

$\mathrm{X}_{1} \ldots \mathrm{X}_{\mathrm{n}}=$ Variabel bebas (independent) pada kepemimpinan dan kinerja

A $\quad=$ Konstanta

$\mathrm{b}_{1}, \mathrm{~b}_{2} \quad=$ Koefisien regresi

e $=$ Standar error

Untuk mengetahui besarnya pengaruh masingmasing variabel bebas terhadap variabel tergantung dilakukan dengan menganalisis nilai $\mathrm{r}^{2}$ parsial sehingga dapat diketahui variabel bebas $(\mathrm{X})$ yang dominan pengaruhnya terhadap variabel tergantung $(\mathrm{Y})$.

\begin{tabular}{|c|c|c|c|}
\hline No. & Variabel & Indikator & Item Pertanyaan \\
\hline \multirow[t]{5}{*}{1.} & Kepemimpinan & 1. Keteladan & Memberi teladan \\
\hline & & 2. Kewibawaan & Berwibawa \\
\hline & & 3. Kecakapan & Cakap dalam mengkoordinasi \\
\hline & & 4. Penyampaian informasi & Informasi jelas atau tidak salah paham \\
\hline & & 5. Pengambilan keputusan & 5. Musyawarah \\
\hline \multirow[t]{6}{*}{2.} & Kinerja dosen & 1. Kualitas hasil & 1.1 Ketelitian dalam pekerjaan \\
\hline & & 2. Kuantitas hasil & 1.2 Perhatian terhadap mutu \\
\hline & & 3. Ketepatan waktu & 2.1 Tugas-tugas selalu ditetapkan suatu target \\
\hline & & & 2.2 Penyelesaian tugas sesuai target \\
\hline & & & $\begin{array}{l}\text { 3.1 Dalam mengerjakan setiap tugas selalu } \\
\text { ditetapkan target waktu }\end{array}$ \\
\hline & & & $\begin{array}{l}\text { 3.2 Dalam menyelesaikan tugas sesuai dengan waktu } \\
\text { yang ditetapkan }\end{array}$ \\
\hline \multirow[t]{5}{*}{3.} & Mutu Pelayanan & 1. Tangibles (bukti langsung) & 1.1. Kondisi Kebersihan dan kenyamanan \\
\hline & & 2. Reliability (kehandalan) & 1.2. Kesesuaian dengan yang dijanjikan \\
\hline & & 3. Responssiveness (daya tanggap & 1.3. Pelayanan yang cepat \\
\hline & & 4. Assurance (jaminan) & 1.4. Stafterpercaya \\
\hline & & 5. Emphaty (empati) & 1.5. Perhatian secara pribadi \\
\hline
\end{tabular}

\section{Teknik Analisis Data}

Teknik analisis data yang digunakan pada penelitian ini adalah sebagai berikut: (a) Analisis Deskriptif dimaksudkan untuk mengetahui seberapa besar distribusi frekuensi jawaban responden terhadap item pertanyaan dalam kuesioner untuk masing-masing variabel kepemimpinan, kinerja dosen dan mutu pelayanan. (b) Analisis regresi linier berganda digunakan untuk mengetahui hubungan kausal antara variabelvariabel dalam penelitian. Menurut Adiningsih (1993)

\section{HASIL DAN PEMBAHASAN}

\section{Deskripsi Responden}

Umur

Secara garis besar terlihat bahwa sebagian besar responden adalah mereka yang ada pada kelompok umur 24-30 yaitu sebanyak 24 orang karyawan $(48,0 \%)$. Kelompok umur terbanyak kedua adalah kelompok umur 31-35 sebanyak 18 orang (36,0\%). Kelompok di atas 36 sebanyak 8 orang $(16,0 \%)$. Hasil temuan 
ini menunjukkan bahwa responden yang diambil sebagai sampel adalah kelompok umur karyawan yang benar-benar masih muda dan produktif.

\section{Jenis Kelamin}

Deskripsi responden berdasarkan jenis kelamin menunjukkan bahwa responden berjenis kelamin lakilaki $30,0 \%$ yaitu sebanyak 15 orang sedangkan wanita terdiri dari $70 \%$ yaitu sebanyak 35 orang. Bisa disimpulkan responden didominasi jenis kelamin perempuan.

\section{Status Pendidikan}

Deskripsi Responden berdasarkan status pendidikan dosen tetap sebanyak 25 orang atau $52 \%$ adalah sarjana strata 1 (S-1) sedangkan 24 orang dosen atau $48 \%$ status pendidikannya adalah strata $2,(\mathrm{~S}-2)$. Bisa disimpulkan bahwa responden masih banyak yang berstatus dosen strata satu (S-1).

\section{Deskripsi Variabel Penelitian}

Berdasarkan hasil pengumpulan data di lapangan, maka diperoleh gambaran mengenai kondisi objek dari variabel yang digunakan dalam penelitian ini, di mana variabel tersebut adalah variabel kepemimpinan, kinerja karyawan dan mutu layanan. Berdasarkan data yang diperoleh dari hasil jawaban responden maka dapat ditentukan nilai masing-masing variabel sebagai dasar untuk mengidentifikasi bagaimana kecenderungan dan variasi tanggapan responden terhadap kuesioner yang telah diajukan.

\section{Kepemimpinan (X1)}

Secara umum penilaian responden pada variabel kepemimpinan. Hasil penelitian menunjukkan bahwa frekuensi jawaban responden pada variabel ditunjukkan dengan nilai rata-rata sebesar 3,45. Artinya responden cukup setuju bahwa kepemimpinan pada Politeknik Negeri Batam sudah baik, karena adanya keteladanan, kewibawaan, kecakapan, penyampaian informasi dan pengambilan keputusan pada kepemimpinan yang saat ini dilakukan.

\section{Kinerja Dosen (X2)}

Secara umum penilaian responden pada variabel kinerja dosen menunjukkan baik. Hasil penelitian menunjukkan bahwa frekuensi jawaban responden ditunjukkan dengan nilai rata-rata sebesar 3,8. Artinya responden setuju bahwa dosen Politeknik Negeri Batam telah melaksanakan tanggung jawab dengan bekerja keras, atas beban kerja, ketelitian, perhatian, peraturan dan target hasil yang harus dicapai. Dimana penyelesaian target pekerjaan lebih dominan, dibandingkan atribut yang lain pada variabel ini.

\section{Mutu Pelayanan}

Secara umum penilaian responden pada variabel ini menunjukkan bahwa rata-rata sebesar 3,81. Bisa dikatakan responden setuju bahwa dosen Politeknik Negeri Batam, sudah melaksanakan mutu pelayanan dengan baik. Responden sudah merasa sangat berharga karena Politeknik Negeri Batam menyiapkan lingkungan kerja yang baik sebagai bukti langsung, dan karyawan sangat diberi kesempatan untuk berprestasi dan pimpinan manajemen sangat memperhatikan kinerja dosen, dan penuh simpati dan daya tanggap terhadap keluhan mahasiswa, hal ini dibuktikan dengan adanya kuesioner umpan balik pada setiap akhir semester. Di mana jaminan atas layanan yang diberikan pada pasien lebih dominan, dibandingkan antribut yang lain pada indikator variabel ini.

\section{Pengujian Hipotesis}

Dalam pengujian hipotesis dilakukan dengan teknik analisis statistik regresi berganda (multiple regression) dengan menggunakan olahan komputer SPSS, seperti tertulis pada Tabel 1.

Tabel 1. Hasil Analisis Regresi

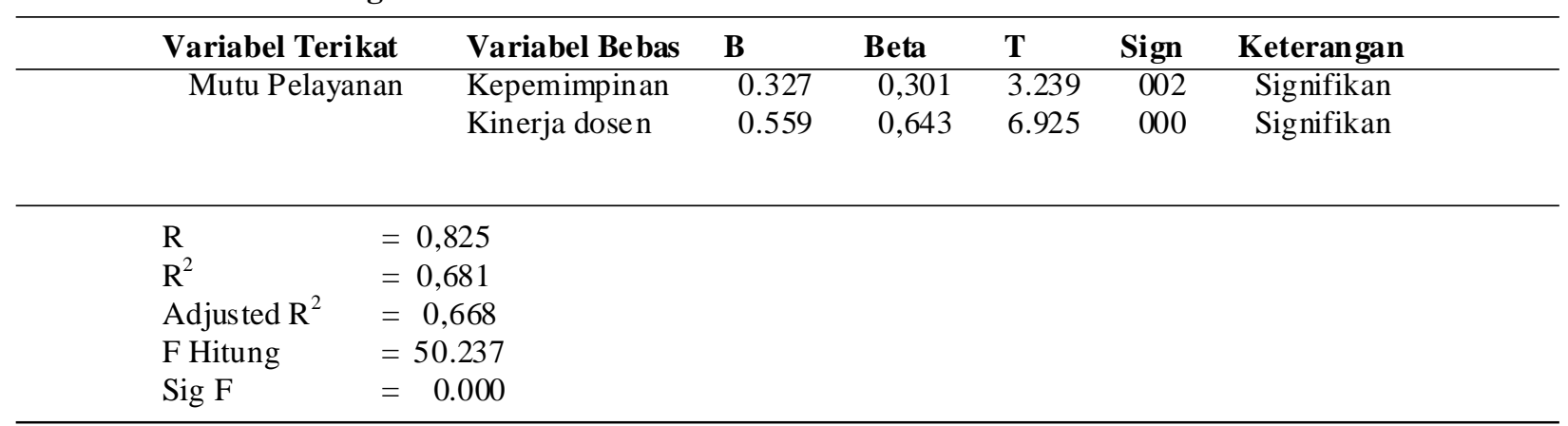

Sumber: Data diolah 
Model estimasi dan persamaam regresi dalam penelitian ini adalah:

$\mathrm{Y}=\mathrm{a}+\mathrm{b}_{1} \mathrm{X}_{1}+\mathrm{b}_{2} \mathrm{X}_{2}+\mathrm{b}_{3} \mathrm{X}_{3}+\ldots \ldots \ldots \ldots+\mathrm{b}_{\mathrm{n}} \mathrm{X}_{\mathrm{n}}+\mathrm{e}$ Mutu Pelayanan $(\mathrm{Y})=0,432+0,327(\mathrm{X} 1)+0,559$ (X2)

\section{Hasil Pengujian Hipotesis 1}

Hasil uji menunjukkan bahwa variabel Kepemimpinan (X1) berpengaruh signifikan terhadap mutu pelayanan (Y) di Politeknik Negeri Batam. Hasil uji ditunjukkan bahwa nilai signifikan sebesar 0,002 dan lebih kecil dari $<0,05$. Hasil uji juga bisa dilihat dari nilai t yaitu $\mathrm{t}_{\text {Hitung }}>\mathrm{t}_{\text {Tabel. }}$ Di mana $3.239>2,009$. Besarnya pengaruh variabel kepemimpinan terhadap mutu pelayanan bisa dilihat pada koefesien regresi sebesar 0,327 atau 32,7\% sedangkan sisanya dapat dijelaskan faktor yang lain sebesar 0,673 atau 67,3\%. Bisa disimpulkan hipotesis pertama diterima.

\section{Hasil Pengujian Hipotesis 2}

Hasil uji menunjukkan bahwa variabel Kinerja dosen (X1) berpengaruh signifikan terhadap Mutu pelayanan (Y) di Politeknik Negeri Batam. Hasil uji ditunjukkan bahwa nilai signifikan sebesar 0,000 dan lebih kecil dari $<0,05$. Hasil uji juga bisa dilihat dari nilai t yaitu $\mathrm{t}_{\text {Hitung }}>\mathrm{t}_{\text {Tabel. }}$ di mana $6.925>2,009$. Besarnya pengaruh variabel kepemimpinan terhadap mutu pelayanan bisa dilihat pada koefesien regresi sebsar 0,559 atau $55,9 \%$ sedangkan sisanya dapat dijelaskan faktor yang lain sebesar 0,441 atau $44,1 \%$. Bisa disimpulkan hipotesis kedua diterima.

\section{Hasil Pengujian Hipotesis 3}

Kepemimpinan dan kinerja dosen secara bersamasama berpengaruh signifikan terhadap mutu layanan di Politeknik Negeri Batam. Setelah dilakukan pengujian melalui analisis regresi terhadap ketiga variabel yaitu Kepemimpinan (X1), Kinerja dosen (X2) terhadap Mutu pelayanan (Y). Bisa ditunjukkan bahwa kedua variabel kepemimpinan, dan kinerja ini memberikan pengaruh yang signifikan terhadap variabel mutu layanan di mana signifikansi $\mathrm{F}$ mempunyai nilai 0,000 . Sedangkan koefisien determinansi $\left(\mathrm{R}^{2}\right)$ sebesar 0,681 atau kontribusi yang diberikan variabel $\mathrm{X} 1$, dan $\mathrm{X} 2$, secara bersama-sama terhadap variabel mutu pelayanan (Y) adalah sebesar $68,1 \%$, sehingga masih ada kontribusi dari variabel lain yaitu sebesar 31,9\% yang tidak diteliti dalam penelitian ini.

\section{PEMBAHASAN}

Penelitian ini telah menemukan bahwa mutu pelayanan pada Institusi pendidikan Politeknik Negeri Batam dapat dijelaskan secara signifikan oleh variabel kepemimpinan dan kinerja dosen. Temuan ini dapat menjadi alternatif model atau cara pengelolaan mutu pelayanan di Politeknik Negeri Batam. Dalam konteks ini pengaruh variabel-variabel penjelas dapat dikaji lebih lanjut untuk mendapatkan bahasan yang lebih komprehensip.

\section{Kepemimpinan Berpengaruh Signifikan terhadap Mutu Pelayanan di Politeknik Negeri Batam}

Berdasarkan hasil analisis dan uji hipotesis penelitian yang telah dikakukan sebelumnya maka pada penelitian ini, didapat bahwa Kepemimpinan berpengaruh signifikan terhadap mutu pelayanan Politeknik Negeri Batam, dengan koefisien regresi sebesar 0,327 $($ sign $=0,002)$. Hal ini menunjukkan bahwa cukup besar peranan faktor kepemimpinan atas kerja karyawan dosen di Politeknik Negeri Batam, bila dihubungkan dengan mutu pelayanan. Faktor kewibawaan, kecakapan, penyampaian informasi dan pengambilan keputusan adalah faktor-faktor pembentuk variabel kepemimpinan. Temuan penelitian ini menginformasikan bahwa faktor-faktor ini mempunyai kaitan yang positif terhadap mutu pelayanan institusi Politeknik Negeri Batam. Pada hakekatnya faktor keteladanan adalah faktor penting pada seorang pemimpin, dimana faktor ini menjadi salah satu faktor yang sangat strategis untuk membuat kepemimpinan menjadi langgeng dan disukai para anak buah. Kewibawaan juga menjadi salah satu yang penting dari seoarang pemimpin, karena pemimpin yang berwibawa akan diperhatikan para pengikutnya. Penyampaian informasi yang baik dan efektif menjadi salah satu modal penting untuk berkomunikasi, disisi lain fakor pengambilan keputusan juga sangat penting dimiliki seorang pemimpin.

Penyampaian informasi yang efektif dari pimpinan ke karyawan merupakan bagian dari komunikasi. Kepemimpinan yang efektif adalah bagian dari tata kelola untuk mengarahkan organisasi dalam hal ini adalah institusi pendidikan agar sesuai dengan tujuan yaitu mutu pelayanan pendidikan di Politeknik Negeri Batam. Pimpinan dalam mengambil keputusan dan kebijakan adalah untuk menyelaraskan, mengarahkan, mendorong, mengevaluasi dan mengelola sumber daya yang ada untuk mencapai tujuan 
organisasi yang dalam hal ini adalah mutu pelayanan pendidikan. Sesuai dengan Siagian (2001) bahwa Kepemimpinan dapat timbul di mana saja, asal terpenuhi unsur-unsur seperti adanya orang yang dipengaruhi dan orang yang mempengaruhi mengarahkan pada tercapainya suatu tujuan.

Kewibawaan dalam memimpin adalah merupakan bagian dari kepemimpinanan, kewibawaan bisa dilihat dari sikap mengambil keputusan dan sikap yang mengarahkan dalam mencapai tujuan, dalam hal ini sikap yang mengarahkan karyawan sesuai dengan tujuan organisasi. Seperti mengarahakan karyawan dosen untuk memenuhi standar mutu pelayanan di Politeknik Negeri Batam. Hal tersebut didukung oleh teori Hersey dan Blanchard (dalam Thoha, 2001) menyatakan dalam hubungannya dengan perilaku pimimpinan, ada dua hal yang biasanya dilakukan seorang pemimpin terhadap bawahan, yakni: (1) perilaku pengarahan, dan (2) perilaku pendukung. Perilaku mengarahkan dapat dirumuskan sebagai sejauh mana seorang pemimpin melibatkan diri dalam kondisi satu arah, seperti: menetapkan peranan yang seharusnya dilakukan bawahan dan lainnya. Perilaku pendukung dalah sejauhmana seorang pemimpin melibatkan diri dalam komunikasi dua arah, misalnya mendengar, menyediakan dukungan dan dorongan, memudahkan interaksi dan melibatkan bawahan dalam pengambilan keputusan.

\section{Kinerja Karyawan Berpengaruh Signifikan ter- hadap Mutu pelayanan di Politeknik Negeri Batam}

Berdasarkan hasil analisis dan uji hipotesis penelitian yang telah dikakukan sebelumnya maka pada penelitian ini di dapat bahwa kinerja dosen adalah signifikan mempengaruhi mutu pelayanan di Politeknik Negeri Batam, dengan koefisien regresi sebesar 0.559 $(\operatorname{sign}=0.000)$. Hal ini menunjukkan bahwa cukup besar peranan faktor kinerja dosen di Politeknik Negeri Batam, bila dihubungkan dengan mutu pelayanan. Faktor kualitas hasil kerja, kuantitas, dan kecepatan waktu adalah faktor-faktor pembentuk variabel kinerja dosen.

Temuan penelitian ini menginformasikan bahwa faktor-faktor ini mempunyai kaitan yang positif terhadap mutu pelayanan di Politeknik Negeri Batam. Penemuan ini sesuai dengan hasil penelitian yang dilakukan oleh Hubeis dan Rahmawati (2011) Secara keseluruhan bahwa ada hubungan antara atribut-atribut pada dimensi mutu pelayanan seperti realiability, responsiveness, emphaty, performance dan tangibles terhadap loyalitas pelanggan dan mutu pelayanan dapat meningkatkan loyalitas pelanggan. Penelitian ini juga menunjukkan bahwa Service quality dibentuk oleh faktor realiability, responsiveness, emphaty, performance dan tangibles. Temuan penelitian ini juga sesuai dengan hasil penelitian Sarwono dan Rohmad (2013) bahwa ada pengaruh yang positif antara kinerja pegawai dan mutu pelayanan pegawai. Temuan penelitian ini sejalan dengan hasil penelitian Nilakusmawati dan Srinadi (2008) bahwa mutu pelayanan di lembaga pendidikan tinggi dipengaruhi oleh indikator-indikator kinerja dosen yaitu faktor empathy (empati) seperti (1) informasi perku-liahan oleh dosen; (2) pengembalian hasil evaluasi/tes oleh dosen; dan (3) keadaan meja-kursi.

\section{Kepemimpinan dan Kinerja Karyawan secara Bersama-Sama Berpengaruh Signifikan terhadap Mutu Pelayanan di Politeknik Negeri Batam}

Berdasarkan hasil analisis dan uji hipotesis penelitian yang telah dikakukan sebelumnya maka pada penelitian ini, di dapat bahwa variabel Kepemimpinan dan variabel kinerja dosen, secara bersama signifikan mempengaruhi mutu pelayanan di Institusi Politeknik Negeri Batam, dengan koefisien determinansi $\left(\mathrm{R}^{2}\right)$ sebesar 0,681. Nilai tersebut menunjukkan bahwa kepemimpinan dan kinerja dosen, akan mendorong naiknya mutu pelayanan Politeknik Negeri Batam sebesar $68.1 \%$. Selain itu nilai korelasi atau hubungan antar variabel adalah kuat yang ditunjukkan dengan nilai 0,825 atau $82,5 \%$

Berdasarkan hasil pengujian hipotesis, bahwa semua dugaan yang telah dihipotesiskan terbukti. Berdasarkan hal tersebut bahwa kepemimpinan dan kinerja dosen Politeknik, terbukti berpengaruh terhadap mutu pelayanan secara parsial maupun secara bersama-sama. Kinerja dosen sangat berpengaruh terhadap mutu layanan seperti halnya politeknik Negeri Batam yang juga menargetkan mutu pelayanan pada mahasiswa. Mutu pelayanan yang baik merupakan tujuan yang harus dicapai dan selalu disempurnakan harapannya, bisa menyempurnakan kuliatas pelayanan pada mahasiswa.

Tuntuntan mutu pelayanan yang baik tergantung dari sikap kepemimpinan dalam manajemen Politeknik Negeri Batam dan Kinerja dosen sebagai tenaga pendidik yang langsung berhadapan dengan mahasiswa melalui kegiatan, pendidikan dan pengajaran, pembinaan akademik dan kemahasiswaan. Penilaian kinerja untuk karyawan dosen harus selalu dilakukan 
sesuai prosedur mutu. Penilaian Kinerja adalah suatu proses bagaimana organisasi atau organisasi mengevaluasi atau menilai prestasi karyawan, kegiatan ini dapat memperbaiki keputusan-keputusan personalia dan memberikan umpan balik kepada para karyawan tentang pelaksanan kerja mereka. (Handoko, 2001)

Pelaksanaan kerja bisa dilihat dari hasil mutu pelayanan pendidikan yang ditentukan oleh kinerja karyawan dalam hal ini adalah dosen yaitu profesionalisme dosen dalam melayani mahasiswa (Nilakusumawati, Srinadi 2008)

Standar mutu pelayanan di Politeknik Negeri Batam juga mengacu pada standar nasional pendidikan PP 19/2005 bahwa ada delapan standar nasional pendidikan yang harus dipenuhi, adapun standar yang terkait adalah salah satunya adalah standar proses, standar pengelolaan pendidikan, standar sarana pendidikan, standar penilaian pendidikan. Standar tersebut merupakan bagian dari mutu pelayanan yang harus ada pada mutu pelayanan pendidikan.

\section{KESIMPULAN DAN SARAN}

\section{Kesimpulan}

Berdasarkan hasil analisis dan uji hipotesis penelitian yang telah dikakukan sebelunya maka dari penelitian ini dapat ditarik kesimpulan sebagai berikut: (1) Kepemimpinan berpengaruh terhadap mutu pelayanan, dengan koefisien regresi sebesar 0.327 ( $p$-value $=$ 0.002). Hal ini menunjukkan bahwa sangat besar peran kepemimpinan bila dihubungkan dengan mutu pelayanan. Kepemimpinan sangat berhubungan dengan Keteladanan, Kewibawaan, Kecakapan, Penyampaian info dan Pengambilan keputusan. Tambah besar keteladanan dan kewibawaan pimpinan maka tambah besar keinginan karyawan untuk berbuat sesuatu demi mutu pelayanan akademik. (2) Kinerja kerja karyawan dosen secara signifikan mempengaruhi mutu pelayanan, dengan koefisien regresi sebesar 0.559 ( $p$-value $=0.000)$. Hal ini menunjukkan bahwa kinerja karyawan, akan mendorong naiknya mutu pelayanan secara langsung sebesar 55,9\%. (3) Kepemimpinan dan kinerja kayawan secara bersama-sama mempengaruhi mutu pelayanan sebesar $68,1 \%$. Hal ini menunjukkan bahwa dengan kepemimpinan yang baik, penuh dengan tanggung jawab, berkarakter dan berwibawa, dan adanya kinerja yang tinggi para karyawan dosen, akan mendorong naiknya mutu pelayanan sebesar $68,1 \%$.

\section{Saran}

Pada penelitian ini variabel hanya difokuskan pada kepemimpinan, kinerja dan mutu pelayanan, sementara itu mutu pelayanan juga sangat berhubungan dengan kepuasan konsumen yaitu mahasiswa, yang mana variabel ini belum termasuk menjadi kajian penelitian. Hal ini dapat menjadi kajian untuk penelitian berikutnya, dan penelitian mendatang dapat diarahkan untuk menjelaskan secara detail tentang fokus secara terapan dalam pengelolaan tenaga pendidik yaitu dosen.

Dan pihak Politeknik Negeri Batam sudah seharusnya lebih memperhatikan mutu pelayanan terhadap Konsumen mahasiswa maupun pihak staf karyawan yang ada di Politeknik, sebagai ujung tombak pelayanan Pembelajaran dan penyelenggara pendidikan berbasis vokasi. Tidak kalah pentinggnya pihak Politeknik seharusnya sudah melaksanakan semua peraturanperaturan yang mengatur tentang operasional kerja dosen, sehingga diharapkan mutu pelayanan dapat dilaksankana sebaik mungkin.

\section{DAFTAR RUJUKAN}

Adiningsih, S. 1993. Statistika. Yogyakarta: BPFE.

Armstrong, M., \& Baron, A. 1998. Performance Management: The New Realities, Institute of Personnel and Development. New York.

As'ad, S.U. 1999. Seri Ilmu dan Sumber Daya Manusia, Psikologi Industri. Yogyakarta: Penerbit Liberty.

Arikunto, S. 1998. Prosedur Penelitian suatu Pendekatan Praktek. Yogyakarta: Rineka Cipta.

Handoko, T.H. 2003. Manajemen Personalia dan Sumber Daya Mansia. Universitas Gajah Mada: Balai Penerbit Fak. Ekonomi.

Hersey, P., dan Ken, B. 1995. Manajemen Perilaku Organisasi, Pendayagunaan Sumber Daya Manusia. Jakarta: Penerbit Erlangga.

Harsey, Blanced, D., terjemahan Thoha. 2001. Bagaimana Memimpin dan Mengawasi Pegawai Anda. Jakarta: Akasara Baru.

Hasibuan, M. 1997. Manajemen Sumber Daya Manusia. Jakarta: CV Haji Masagung.

Handoko, H. 1998. Manajemen Personalia dan Sumber Daya Manusia. Edisi 2. Yokyakarta: BBPE.

Hubeis, R. 2011. Hubungan Mutu Pelayanan dengan Loyalitas Pelanggan Jasa Pengiriman Paket pada Kantor Pos Kota Depok Jurnal Manajemen dan Organisasi Vol II, No. 1. April 2011.

Kotler, P. 1995, 1996, 1997, 1998, 2000. Manajemen Pemasaran: Analisis, Implemen tasi dan Pengendalian, Buku Satu, Edisi Kedelapan. Jakarta: Penerbit Salemba Empat. 
..... Marketing and Introduction (Fifth Edition). New Jersey: Prentice Hall Inc.

Mangkunegara, P.A. 2000. Manajemen Sumber Daya Manusia Perusahaan. Bandung: Rosda.

Nilakusmawati, S. 2008. Faktor-faktor Penentu Kepuasan Mahasiswa terhadap Pelayanan Fakultas Sebagai Lembaga Pendidikan. (Studi Kasus di FMIPA, Universitas Udayana) Jurnal Cakrawala Pendidikan, November 2008, Th. XXVII, No. 3.

Riduwan. 2004, Metode dan Teknik Menyusun Tesis. Bandung: Alfabeta.

Sarwono dan Rohmad. 2013. Pengaruh Kinerja Pegawai dan Mutu Pelayanan Pegawai terhadap Kepuasan Masyarakat dalam Memperoleh Kartu tanda Penduduk dan Kartu Keluarga di Kantor Kecamatan Baki. Jurnal Manajemen Bisnis Syariah, No.1 Januari 2013.

Sekaran U. 2006. Metodologi Penelitian untuk Bisnis. Jilid 1. Edisi 4 . Jakarta: Salemba Empat.

Schuler, R.S., \& Jackson, S.E. 2002. Manajemen Sumber
Daya Manusia Menghadapi Abad Ke-21, Alih bahasa Nurdin, S dan Dewi Kartini Y. Jakarta: Erlangga. Siagian, P.S. 2001. Manajemen Sumber Daya Manusia. Yogyakarta: BPFE-UTS.

Simanjuntak, P. 1985. Produktivitas dan Tenaga Kerja Indonesia. Jakarta: FEUI.

Siagian, P.S. 1996. Manajemen Sumber Daya Manusia. Jakarta: Bumi Aksara.

Singarimbun, M., dan Effendy, S. 1998. Metode Penelitian Survey. Jakarta: LP3ES.

Singarimbun, M. 2006. Metode Penelitian Survai. Jakarta: LP3ES.

Thoha, M. 2001. Perilaku Organisasi Konsep Dasar dan Aplikasinya. Jakarta: Raja Grafindo Persada.

Tannenbaum, R., Irving, R.W., and Fred, M. 1973. Leadership and Organization: A Behavioral Science Approach. NewYork: McGraw-Hill Book Company, Inc.

Zeithaml, Valarie, A., Leonardo, L., and Parasuraman, A. 1998. The Behavioral Consequences of Service Quality, Journal of Marketing, Vol. 60. April, pp.31-46. 